data from statistically stationary processes where the record is much longer than the longest wavelength of interest. Most fossil time series violate all three constraints. The fossil record is our only possible data source for studying the long-term dynamics of Earth's biotic system, but such studies require carefully designed hypothesis tests.

James W. Kirchner*, Anne Weil $\dagger$

${ }^{\star}$ Department of Geology and Geophysics,

University of California, Berkeley,

California 94720, USA

e-mail:kirchner@geomorph.berkeley.edu

$\dagger$ Department of Integrative Biology and University of California Museum of Paleontology,

University of California, Berkeley,

California 94720, USA

1. Solé, R. V., Manrubia, S. C., Benton, M. \& Bak, P. Nature 388, 764-767 (1997).

2. Benton, M. J. (ed.) The Fossil Record 2 (Chapman \& Hall, London, 1993).

3. House, M. R. Phil. Trans. R. Soc. Lond. B 325, 307-326 (1989).

4. Patterson, R. T. \& Fowler, A. D. Geology 24, 215-218 (1996).

5. Bak, P. \& Sneppen, K. Phys. Rev. Lett. 71, 4083-4086 (1993).

6. Solé, R. V. \& Manrubia, S. C. Phys. Rev. E 54, R42-R45 (1996),

7. Connor, E. F. in Patterns and Processes in the History of Life (eds Raup, D. M. \& Jablonski, D.) 119-147 (Springer, Berlin, 1986).

8. Blackman, R. B. \& Tukey, J. W. The Measurement of Power Spectra from the Point of View of Communications Engineering (Dover, New York, 1958).

\section{Arsenic poisoning of Bangladesh groundwater}

In Bangladesh and West Bengal, alluvial Ganges aquifers used for public water supply are polluted with naturally occurring arsenic, which adversely affects the health of millions of people. Here we show that the arsenic derives from the reductive dissolution of arsenic-rich iron oxyhydroxides, which in turn are derived from weathering of base-metal sulphides. This finding means it should now be possible, by sedimentological study of the Ganges alluvial sediments, to guide the placement of new water wells so they will be free of arsenic.

As many as a million water wells drilled into Ganges alluvial deposits in Bangladesh and West Bengal may be contaminated with $\operatorname{arsenic}^{1-6}$. Measured arsenic concentrations $^{1-6}$ reach up to $1,000 \mu \mathrm{g} \mathrm{l}^{-1}$, which is above the limit set for drinking water in Bangladesh $\left(50 \mu \mathrm{g} \mathrm{l}^{-1}\right)$ or that recommended by the World Health Organization $\left(10 \mu \mathrm{g} \mathrm{l}^{-1}\right)$. Consumption of this contaminated water has led to widespread death and disease ${ }^{1-6}$.

Arsenic has been reported to derive from the oxidation of arsenic-rich pyrite in the aquifer sediments as atmospheric oxygen invades the aquifer in response to a lowering of the water level by abstraction ${ }^{4,5}$. However, this explanation is not consistent with the following observations ${ }^{3}$, made on

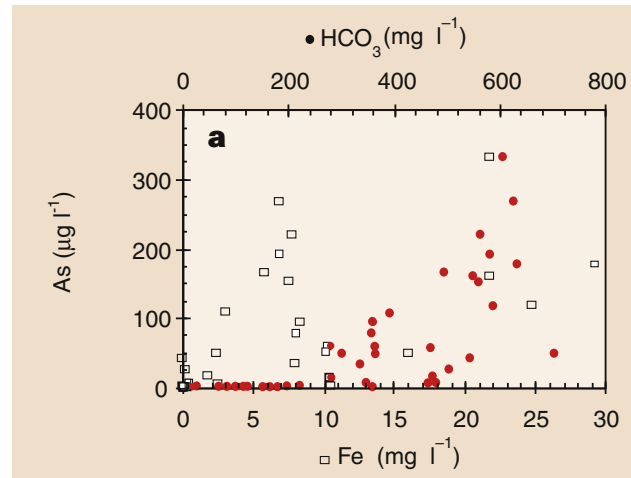

Figure 1 Arsenic chemistry of groundwater and aquifer sediment from Bangladesh. a, Arsenic correlates with dissolved iron and with bicarbonate concentrations above 300 mg per litre; the latter is a by-product of iron oxyhydroxide reduction. b, Relation of arsenic and iron in aquifer sediments; arsenic concentrations are up to 15 times higher than crustal abundance.

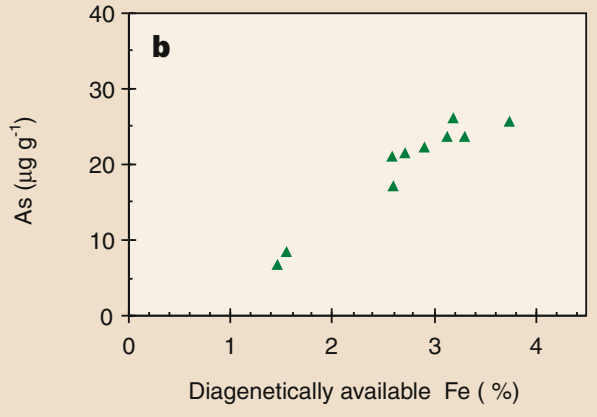

46 wells, typical of those in Bangladesh, that were sampled during May and June of 1997: in oxic (shallow) wells, arsenic concentrations are mostly below $50 \mu \mathrm{g} \mathrm{l}^{-1}$; in anoxic waters, arsenic concentrations ( $\leqslant 260 \mu \mathrm{g} \mathrm{l}^{-1}$ ) correlate with concentrations of dissolved iron ( $\leqslant 29 \mathrm{mg} \mathrm{l}^{-1}$ ) and bicarbonate ( Fig. 1a); and arsenic concentrations increase with depth in wells at Manikganj, Faridpur and Tungipara. These observations suggest that arsenic is released when arsenic-rich iron oxyhydroxides are reduced in anoxic groundwater ${ }^{6}$, a process that solubilizes iron and its absorbed load and increases bicarbonate concentration. Sedimentary iron oxyhydroxides are known to scavenge $\operatorname{arsenic}^{7}$ and, in Ganges aquifer sediments, concentrations of diagenetically available iron $(\leqslant 3.7 \%)$ and arsenic ( $\leqslant 26$ p.p.m.) correlate well $^{3}$ (Fig. 1b).

The arsenic-rich groundwater is mostly restricted to the alluvial aquifers of the Ganges delta ${ }^{3,6}$. The source of arsenic-rich iron oxyhydroxides must therefore lie in the Ganges source region upstream of Bangladesh. Weathered base-metal deposits are known to occur ${ }^{6,8-10}$ in the Ganges basin (at Bihar, Uttar Pradesh, West Bengal), so weathering of these arsenic-rich base-metal sulphides must have supplied arsenic-rich iron oxyhydroxide to downstream Ganges sediments during Late Pleistocene-Recent times. The arsenic-rich iron oxyhydroxides are now being reduced, causing the present problem. Reduction is driven by concentrations of sedimentary organic matter ${ }^{3}$ of up to $6 \%$.

A knowledge of the sedimentary architecture and distribution of iron, arsenic and reductant carbon in Ganges alluvial sediments will allow the development of a predictive model to guide future aquifer development in a way that minimizes arsenic pollution. Furthermore, as dissolved iron is oxidized it precipitates as iron oxyhydroxide, which scavenges arsenic from solution. It follows that simple aeration of anoxic Bangladesh groundwater, followed by settling, should remove a considerable amount of arsenic from solution. This simple treatment could be performed on a household or village scale. Although the disposal of the arsenic-rich iron oxyhydroxides would require special arrangement, this would be preferable to either the widespread poisoning that now exists or a return to the use of contaminated surface water for public consumption.

Ross Nickson ${ }^{\star}$, John McArthur ${ }^{\star}$, William Burgess ${ }^{\star}$, Kazi Matin Ahmed $\dagger$, Peter Ravenscroft $\neq$, Mizanur Rahman $\$$ ${ }^{*}$ Geological Sciences,

University College London,

Gower Street, London WC1E 6BT, UK

$\dagger$ Department of Geology,

University of Dhaka,

Dhaka 1000, Bangladesh 122 Gulshan Avenue, Dhaka-1212, Bangladesh $\S$ GWCII, Bangladesh Water Development Board, 72 Green Road, Dhaka 1207, Bangladesh

1. Pearce, F. The Guardian (19 \& 26 February, 1997).

2. Dhar, R. K. et al. Curr. Sci. 73, 48-59 (1997).

3. Nickson, R. Thesis, University College London (1997).

4. Das, D, Basu, G., Chowdhury, T. R. \& Chakraborty, D. in Proc. Int. Conf. Arsenic in Groundwater (Calcutta,1995).

5. Saha, A. K. \& Chakrabarti, C. in Proc. Int. Conf. Arsenic in Groundwater (Calcutta, 1995).

6. Bhattacharya, P., Chattargee, D. \& Jacks, G. Water Res. Dev. 13, 79-92 (1997).

7. Mok, W. M. \& Wai, C.M. Arsenic in the Environment (ed. Nriagu, J. O.) 99-117 (Wiley, New York, 1994).

8. Ghosh, S. \& De, S. Ind. J. Earth Sci. 22, 183-189 (1995).

9. Bannerjee, D. K. Mineral Resources of India (World Press, Calcutta, 1992).

10. Wadia, D. N. Geology of India, 4th edn (Tata, 1975). $\ddagger$ Mott MacDonald International Ltd, 